\title{
Convenient synthesis of spiroindole derivatives via palladium-catalyzed cyclization of propargyl chlorides
}

\section{$\operatorname{AUTHOR}(\mathrm{S})$ :}

Iwata, Akira; Inuki, Shinsuke; Oishi, Shinya; Fujii, Nobutaka; Ohno, Hiroaki

\section{CITATION:}

Iwata, Akira ... [et al]. Convenient synthesis of spiroindole derivatives via palladiumcatalyzed cyclization of propargyl chlorides. Tetrahedron 2015, 71(37): 6580-6585

\section{ISSUE DATE:}

2015-09

URL:

http://hdl.handle.net/2433/202050

\section{RIGHT:}

(c) 2015. This manuscript version is made available under the CC-BY-NC-ND 4.0 license

http://creativecommons.org/licenses/by-nc-nd/4.0/; The full-text file will be made open to the public on 9 May 2017 in accordance with publisher's 'Terms and Conditions for Self-Archiving'.; この論文は出版社版でありません。引用の際に は出版社版をご確認じ利用ください。; This is not the published version. Please cite only the published version. 


\section{Graphical Abstract}

To create your abstract, type over the instructions in the template box below.

Fonts or abstract dimensions should not be changed or altered.

Convenient synthesis of spiroindole

Leave this area blank for abstract info.

derivatives via palladium-catalyzed cyclization of propargyl chlorides

Akira Iwata, Shinsuke Inuki, Shinya Oishi, Nobutaka Fujii, Hiroaki Ohno

Graduate School of Pharmaceutical Sciences, Kyoto University, Sakyo-ku, Kyoto 606-8501, Japan

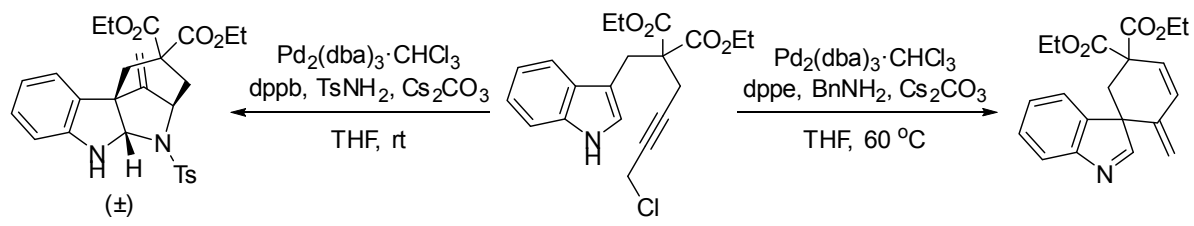




\title{
Convenient synthesis of spiroindole derivatives via palladium-catalyzed cyclization of propargyl chlorides
}

\author{
Akira Iwata, Shinsuke Inuki, ${ }^{\dagger}$ Shinya Oishi, Nobutaka Fujii*, Hiroaki Ohno* \\ Graduate School of Pharmaceutical Sciences, Kyoto University, Sakyo-ku, Kyoto 606-8501, Japan
}

\section{ARTICLE INFO}

\section{Article history:}

Received

Received in revised form

Accepted

Available online

\section{Keywords:}

palladium

spiroindole

cascade cyclization

catalytic asymmetric reaction

\section{Introduction}

The palladium-catalyzed reactions of propargyl compounds provide efficient approaches for the formation of carbon-carbon and carbon-heteroatom bonds. ${ }^{1}$ The pioneering work of Tsuji and co-workers revealed that double nucleophilic additions proceeded at the central and terminal carbons of the propargylic moiety when soft carbon- or oxo-nucleophiles were employed. ${ }^{2}$ This chemistry is particularly useful for the construction of carbo- and heterocyclic frameworks, including furans ${ }^{3}{ }^{3}$ cyclobutanes, ${ }^{4}$ indenes, ${ }^{5}$ cyclopentanones, ${ }^{6}$ cyclic carbonates, ${ }^{7}$ benzofurans, ${ }^{8}$ and indoles, ${ }^{9}$ especially when it is used in combination with an interor intramolecular nucleophilic addition reaction as the terminating step.

Spirocyclic compounds are currently attracting considerable interest in organic chemistry because of their unique molecular structure and diverse biological activities. ${ }^{10}$ In particular, enantioenriched spiroindoles and spiroindolines represent important structural motifs that can be found in a wide range of biologically active natural products and synthetic compounds. ${ }^{11}$ As part of our ongoing efforts towards the construction of heterocyclic frameworks based on the palladium-catalyzed reactions of propargyl/allenic compounds, we recently became interested in the intramolecular nucleophilic addition reactions of indoles as a strategy for the synthesis of spiroindoles. It was envisaged that this strategy would provide facile access to tetracyclic spiroindolines when it was used in combination with the intermolecular nucleophilic cyclization of an external nucleophile
(Scheme 1, eq. 1, path a). We also expected that running the same reaction without using an external nucleophile would promote $\beta$-hydride elimination (path $\mathrm{b}$ ) to produce spiroindoles bearing a conjugated diene moiety (eq. 2).

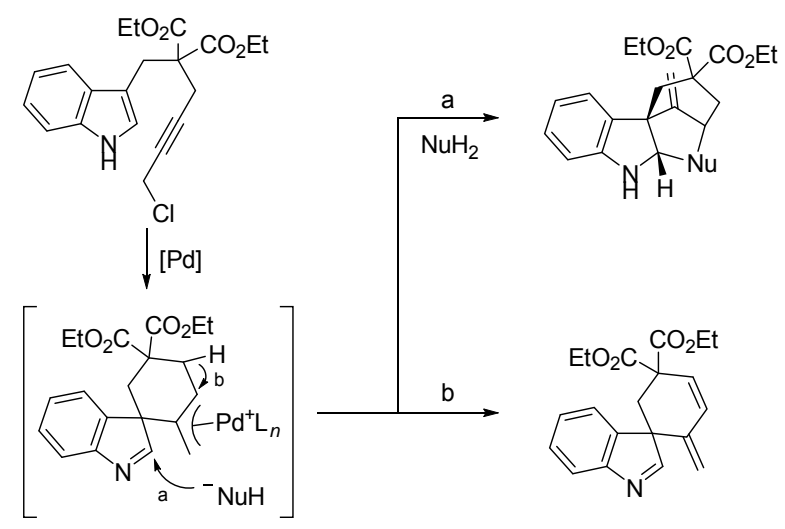

Scheme 1. Our concept: palladium-catalyzed spirocyclization of indole-based propargyl compounds

In 2013, Hamada and co-workers reported the development of a palladium-catalyzed intramolecular spirocyclization of phenolbased propargylic carbonates (Scheme 2, eq. 3). ${ }^{12}$ When tryptamine-derived carbonates were used, this reaction produced spiroindoles bearing an azepine moiety. Immediately after our communication in $2014,{ }^{13}$ the groups of Rawal ${ }^{14 a}$ and You ${ }^{14 b}$ independently reported the intermolecular reactions of indole-

\footnotetext{
* Corresponding author. Tel.: +81-75-753-4571; fax:+81-75-753-4570; e-mail: hohno@pharm.kyoto-u.ac.jp

* Corresponding author. Tel.: +81-75-753-4551; fax: +81-75-753-4570; e-mail: nfujii@pharm.kyoto-u.ac.jp
} 
Tetrahedron

based dual nucleophiles and propargyl carbonates as general strategies for the synthesis of spiroindoles (eq. 4). In this paper, we report the full details of our recent investigations into construction of tetracyclic spiroindolines (eq. 1) and conjugated diene-type spiroindoles (eq. 2) via the palladium-catalyzed cyclization of propargyl chlorides. Our attempts to achieve a catalytic asymmetric spirocyclization onto a propargylpalladium species have also been presented

Hamada and Nemoto ${ }^{12}$

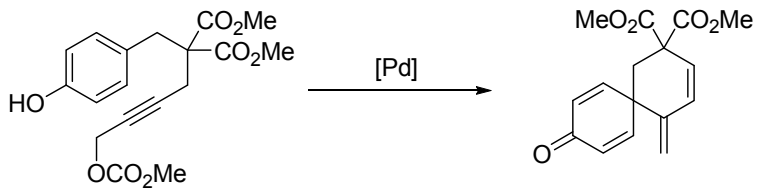

Rawal $^{14 a}$ and You ${ }^{14 b}$

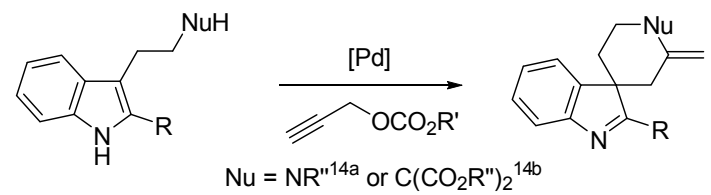

Scheme 2. Related palladium-catalyzed spirocyclization reaction using propargyl compounds

\section{Results and discussion}

The route used for the preparation of substrates $\mathbf{5 a}-\mathbf{c}$ is shown in Scheme 3. In accordance with a literature procedure, ${ }^{15}$ gramine (1) was converted to the corresponding malonate 2 . The subsequent alkylation of $\mathbf{2}$ followed by a desilylation reaction afforded propargyl alcohol 4. Substrates 5a and $\mathbf{5 b}$ were obtained by the reaction of 4 with $\mathrm{NCS} / \mathrm{PPh}_{3}$ or $\mathrm{ClCO}_{2} \mathrm{Me} /$ pyridine, respectively. Bromoallene 5c was prepared from propargyl alcohol 6 using an established procedure for the formation of bromoallenes. ${ }^{16}$ The treatment of $\mathbf{6}$ with TrisCl (Tris $=2,4,6$ triisopropylbenzenesulfonyl) and DMAP gave the corresponding sulfonate, which was converted to bromoallene 7 by treatment with $\mathrm{CuBr} \cdot \mathrm{SMe}_{2}$ in the presence of $\mathrm{LiBr}$. Finally, the introduction of the indole unit to 7 was achieved by its reaction with gramine (1) in the presence of ethyl propiolate to give bromoallene 5c. The other substrates were also prepared in the same manner (see Supplementary material).

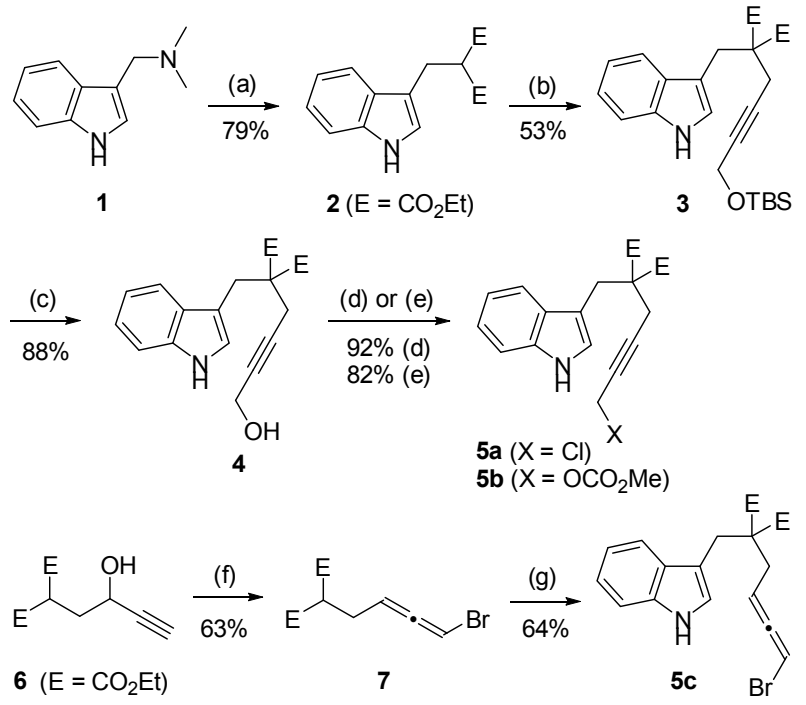

Scheme 3. Preparation of substrates 5a-c. (a) diethyl malonate, ethyl propiolate, $\mathrm{Et}_{2} \mathrm{O}$, rt; (b) $\mathrm{BrCH}_{2} \mathrm{C} \equiv \mathrm{CCH}_{2} \mathrm{OTBS}$, $\mathrm{NaH}$, THF,
$0{ }^{\circ} \mathrm{C}$ to $\mathrm{rt}$; (c) TBAF, THF, $0{ }^{\circ} \mathrm{C}$; (d) $\mathrm{NCS}, \mathrm{PPh}_{3}, \mathrm{CH}_{2} \mathrm{Cl}_{2}, \mathrm{rt}$; (e) $\mathrm{ClCO}_{2} \mathrm{Me}$, pyridine, $\mathrm{CH}_{2} \mathrm{Cl}_{2}, 0{ }^{\circ} \mathrm{C}$; (f) TrisCl, DMAP, $\mathrm{CH}_{2} \mathrm{Cl}_{2}$, then $\mathrm{CuBr} \cdot \mathrm{SMe}_{2}, \mathrm{LiBr}, \mathrm{THF}, 50{ }^{\circ} \mathrm{C}$; (g) 1, ethyl propiolate, $\mathrm{Et}_{2} \mathrm{O}$, rt.

Our studies began with a series of screening experiments to identify the optimal reaction conditions using propargyl chloride 5a as a model substrate (Table 1). The reaction of 5a with 5 mol \% $\mathrm{Pd}\left(\mathrm{PPh}_{3}\right)_{4}, \mathrm{TsNH}_{2}$ and $\mathrm{Cs}_{2} \mathrm{CO}_{3}$ in THF gave spiroindole 9a, the $\beta$-hydride elimination product, in only $20 \%$ yield (entry 1). When the reaction was conducted in the presence of $5 \mathrm{~mol} \%$ $\operatorname{Pd}(\mathrm{dba})_{2}$ and the bidentate ligand 1,1'bis(diphenylphosphino)ferrocene (dppf), the desired reaction proceeded smoothly to afford the tetracyclic spiroindoline 8a in $47 \%$ yield (entry 2). A variety of different inorganic bases (entries 3-5), ligands (entries 6-10) and solvents (entries 11-13) were also screened against the reaction, and the results revealed that the use of 1,4-bis(diphenylphosphino)butane (dppb) as the ligand with $\mathrm{Cs}_{2} \mathrm{CO}_{3}$ as the base in THF gave the best results, with compound $\mathbf{8 a}$ being isolated in $\mathrm{ca}$. $72 \%$ yield (entry 9 ). However, the main problem with these conditions was found to be poor reproducibility. Operating under the assumption that the poor reproducibility of these conditions was related to the purity of $\mathrm{Pd}(\mathrm{dba})_{2}$, we investigated the use of $\mathrm{Pd}_{2}(\mathrm{dba})_{3} \cdot \mathrm{CHCl}_{3}$ following its recrystallization from $\mathrm{CHCl}_{3} .{ }^{17}$ This change afforded the desired product $\mathbf{8 a}$ in $72 \%$ yield reproducibly (entry 14 ).

With the optimized conditions in hand, we proceeded to examine the performance of the reaction in the presence of a variety of different nucleophiles. The results are summarized in Table 1 (entries 15-19) and Scheme 4. The reaction with sulfonamides (e.g., $\mathrm{PhSO}_{2} \mathrm{NH}_{2}, \mathrm{MtsNH}_{2}, \mathrm{NsNH}_{2}$, and $\mathrm{MsNH}_{2}$ ) gave the corresponding tetracyclic spiroindolines $\mathbf{8 b}-\mathbf{e}$ in moderate yields (entries 15-18). In contrast, benzylamine was found to be inert as the external nucleophile, with the $\beta$-hydride elimination product 9a being isolated as the major product (entry 19). Interestingly, the use of dimethyl malonate as the nucleophile resulted in the formation of the regioisomeric spiroindoline 10a $(17 \%)$ and spiroindole 9a $(15 \%)$ as shown in Scheme 4 . The use of acetyl acetone, which is a more acidic carbon nucleophile than dimethyl malonate, led to an increase in the yield of spiroindoline 10b $(50 \%)$, along with spiroindole 9a $(20 \%)$.

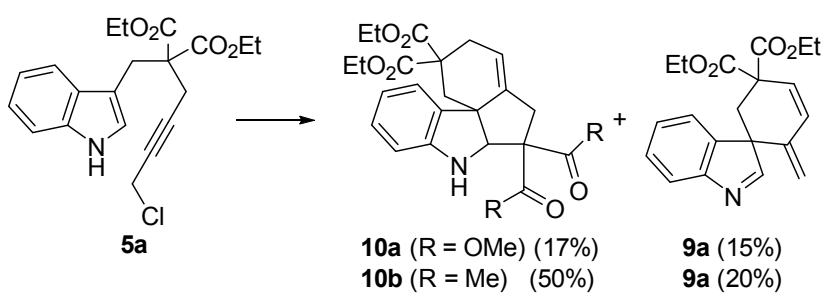

Scheme 4. Reaction with carbon nucleophiles. Reaction conditions: $\mathrm{Pd}_{2}(\mathrm{dba})_{3} \cdot \mathrm{CHCl}_{3}(2.5 \mathrm{~mol} \%)$, dppb (10 mol \%), $\mathrm{Cs}_{2} \mathrm{CO}_{3}$ and $\mathrm{CH}_{2}(\mathrm{COR})_{2}$ in $\mathrm{THF}$ at $\mathrm{rt}$.

It is well known that bromoallenes are the synthetic equivalents of propargyl compounds including chlorides and carbonates in palladium-catalyzed transformations. ${ }^{18}$ With this in mind, we examined the reactions of propargyl carbonate $\mathbf{5 b}$ and bromoallene 5c (Scheme 5). Unfortunately, these reactions gave the desired spiroindoline 8a in only $8-14 \%$ yield. These results therefore demonstrated that substrates of this type are less effective for this reaction than propargyl chloride 5a. 


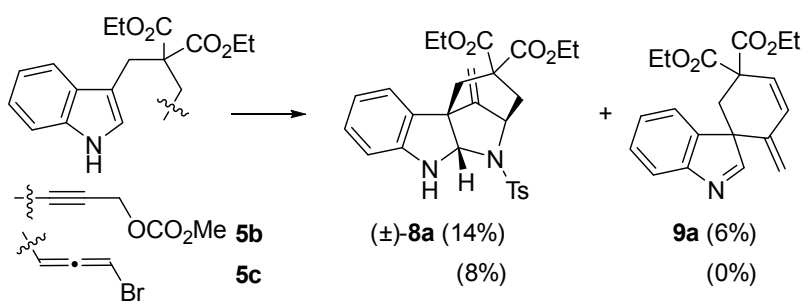

Scheme 5. Reaction of carbonate $\mathbf{5 b}$ and bromoallene $\mathbf{5 c}$. Reaction conditions: $\mathrm{Pd}_{2}(\mathrm{dba})_{3} \cdot \mathrm{CHCl}_{3}(2.5 \mathrm{~mol} \%)$, dppb $(10$ $\mathrm{mol} \%), \mathrm{TsNH}_{2}$ and $\mathrm{Cs}_{2} \mathrm{CO}_{3}$ in $\mathrm{THF}$ at rt.

Table 1. Optimization of the reaction conditions and the reaction with various nitrogen nucleophiles.
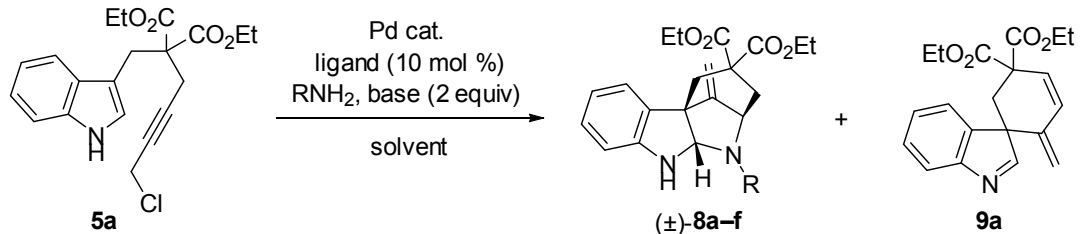

$( \pm)-8 \mathbf{a}-\mathbf{f}$

\begin{tabular}{|c|c|c|c|c|c|c|c|c|c|c|}
\hline \multirow{2}{*}{ entry } & \multirow{2}{*}{$\mathrm{Pd}(\mathrm{mol} \%)$} & \multirow{2}{*}{ ligand } & \multirow{2}{*}{$\mathrm{RNH}_{2}$ (equiv) } & \multirow{2}{*}{ Base } & \multirow{2}{*}{ solvent (M) } & \multirow{2}{*}{$\begin{array}{l}\text { temp } \\
\left({ }^{\circ} \mathrm{C}\right)\end{array}$} & \multirow{2}{*}{$\begin{array}{l}\text { time } \\
\text { (h) }\end{array}$} & \multicolumn{3}{|c|}{$\%$ yield $^{a}$ (product) } \\
\hline & & & & & & & & 8 & & $9 a$ \\
\hline 1 & $\mathrm{Pd}\left(\mathrm{PPh}_{3}\right)_{4}(5)$ & $\left(\mathrm{PPh}_{3}\right)$ & $\mathrm{TsNH}_{2}(1)$ & $\mathrm{Cs}_{2} \mathrm{CO}_{3}$ & THF $(0.1)$ & 60 & 24 & 0 & & 20 \\
\hline 2 & $\mathrm{Pd}(\mathrm{dba})_{2}(5)$ & $\mathrm{dppf}^{b}$ & $\mathrm{TsNH}_{2}(1)$ & $\mathrm{Cs}_{2} \mathrm{CO}_{3}$ & THF $(0.1)$ & 50 & 0.5 & 47 & (8a) & 5 \\
\hline 3 & $\operatorname{Pd}(\mathrm{dba})_{2}(5)$ & dppf & $\mathrm{TsNH}_{2}(1)$ & $\mathrm{K}_{2} \mathrm{CO}_{3}$ & THF $(0.1)$ & 50 & 3 & 15 & (8a) & 6 \\
\hline 4 & $\operatorname{Pd}(\mathrm{dba})_{2}(5)$ & dppf & $\mathrm{TsNH}_{2}(1)$ & $\mathrm{CaCO}_{3}$ & THF (0.1) & 60 & 24 & 0 & & 0 \\
\hline 5 & $\mathrm{Pd}(\mathrm{dba})_{2}(5)$ & dppf & $\mathrm{TsNH}_{2}(1)$ & $\mathrm{NaHCO}_{3}$ & THF $(0.1)$ & 60 & 24 & 0 & & 0 \\
\hline 6 & $\operatorname{Pd}(\mathrm{dba})_{2}(5)$ & $\mathrm{dppm}^{c}$ & $\mathrm{TsNH}_{2}(1)$ & $\mathrm{Cs}_{2} \mathrm{CO}_{3}$ & THF $(0.1)$ & 60 & 24 & 0 & & 17 \\
\hline 7 & $\operatorname{Pd}(\mathrm{dba})_{2}(5)$ & $\mathrm{dppe}^{d}$ & $\mathrm{TsNH}_{2}(1)$ & $\mathrm{Cs}_{2} \mathrm{CO}_{3}$ & THF $(0.1)$ & 60 & 7 & 22 & (8a) & 62 \\
\hline 8 & $\mathrm{Pd}(\mathrm{dba})_{2}(5)$ & $\mathrm{dppp}^{e}$ & $\mathrm{TsNH}_{2}(1)$ & $\mathrm{Cs}_{2} \mathrm{CO}_{3}$ & THF $(0.1)$ & 50 & 1 & 29 & (8a) & 6 \\
\hline 9 & $\mathrm{Pd}(\mathrm{dba})_{2}(5)$ & $\mathrm{dppb}^{f}$ & $\mathrm{TsNH}_{2}(1)$ & $\mathrm{Cs}_{2} \mathrm{CO}_{3}$ & THF $(0.1)$ & $\mathrm{rt}$ & 2.5 & ca. 72 & (8a) & 3 \\
\hline 10 & $\mathrm{Pd}(\mathrm{dba})_{2}(5)$ & dpppe $e^{g}$ & $\mathrm{TsNH}_{2}(1)$ & $\mathrm{Cs}_{2} \mathrm{CO}_{3}$ & THF $(0.1)$ & 50 & 5 & 37 & $(\mathbf{8 a})$ & 2 \\
\hline 11 & $\operatorname{Pd}(\mathrm{dba})_{2}(5)$ & $\mathrm{dppb}$ & $\mathrm{TsNH}_{2}(1)$ & $\mathrm{Cs}_{2} \mathrm{CO}_{3}$ & dioxane $(0.1)$ & 70 & 20 & ca. 13 & (8a) & 3 \\
\hline 12 & $\operatorname{Pd}(\mathrm{dba})_{2}(5)$ & dppb & $\mathrm{TsNH}_{2}(1)$ & $\mathrm{Cs}_{2} \mathrm{CO}_{3}$ & $\operatorname{DMF}(0.1)$ & $\mathrm{rt}$ & 2.5 & ca. 59 & (8a) & 1 \\
\hline 13 & $\operatorname{Pd}(\mathrm{dba})_{2}(5)$ & $\mathrm{dppb}$ & $\mathrm{TsNH}_{2}(1)$ & $\mathrm{Cs}_{2} \mathrm{CO}_{3}$ & $\mathrm{CH}_{3} \mathrm{CN}(0.1)$ & 40 & 2 & ca. 54 & (8a) & 1 \\
\hline 14 & $\mathrm{Pd}_{2}(\mathrm{dba})_{3} \cdot \mathrm{CHCl}_{3}(2.5)$ & dppb & $\mathrm{TsNH}_{2}(1.5)$ & $\mathrm{Cs}_{2} \mathrm{CO}_{3}$ & THF (0.067) & $\mathrm{rt}$ & 3 & 72 & (8a) & 5 \\
\hline 15 & $\mathrm{Pd}_{2}(\mathrm{dba})_{3} \cdot \mathrm{CHCl}_{3}(2.5)$ & $\mathrm{dppb}$ & $\mathrm{PhSO}_{2} \mathrm{NH}_{2}(1.5)$ & $\mathrm{Cs}_{2} \mathrm{CO}_{3}$ & THF (0.067) & $\mathrm{rt}$ & 5 & 64 & $(\mathbf{8 b})$ & 6 \\
\hline 16 & $\mathrm{Pd}_{2}(\mathrm{dba})_{3} \cdot \mathrm{CHCl}_{3}(2.5)$ & dppb & $\mathrm{MtsNH}_{2}{ }^{h}(1.5)$ & $\mathrm{Cs}_{2} \mathrm{CO}_{3}$ & THF (0.067) & $\mathrm{rt}$ & 3.5 & 55 & $(\mathbf{8 c})$ & 9 \\
\hline 17 & $\mathrm{Pd}_{2}(\mathrm{dba})_{3} \cdot \mathrm{CHCl}_{3}(2.5)$ & dppb & $\mathrm{NsNH}_{2}(1.5)$ & $\mathrm{Cs}_{2} \mathrm{CO}_{3}$ & THF (0.067) & 60 & 2 & 43 & $(\mathbf{8 d})$ & 15 \\
\hline 18 & $\mathrm{Pd}_{2}(\mathrm{dba})_{3} \cdot \mathrm{CHCl}_{3}(2.5)$ & dppb & $\mathrm{MsNH}_{2}(1.5)$ & $\mathrm{Cs}_{2} \mathrm{CO}_{3}$ & THF (0.067) & 60 & 24 & 68 & $(\mathbf{8 e})$ & 10 \\
\hline 19 & $\mathrm{Pd}_{2}(\mathrm{dba})_{3} \cdot \mathrm{CHCl}_{3}(2.5)$ & $\mathrm{dppb}$ & $\mathrm{BnNH}_{2}(1.5)$ & $\mathrm{Cs}_{2} \mathrm{CO}_{3}$ & THF (0.067) & 60 & 7 & 0 & $(\mathbf{8 f})$ & 54 \\
\hline
\end{tabular}

$a \quad$ Isolated yields. $\quad b \quad$ 1,1'-bis(diphenylphosphino)ferrocene $\quad c \quad$ bis(diphenylphosphino)methane. $\quad d \quad 1,2$-bis(diphenylphosphino)ethane. $e \quad 1,3-$ bis(diphenylphosphino)propane. ${ }^{f}$ 1,4-bis(diphenylphosphino)butane. ${ }^{g}$ 1,5-bis(diphenylphosphino)pentane. ${ }^{h}$ Mts $=2,4,6$-trimethylbenzenesulfonyl.

We next examined the scope and limitations of the reaction using a series of different indole substrates (Table 2). $\mathrm{N}$ Substituted indoles 5d and 5e did not produce the spirocyclic products (entries 1 and 2). In contrast, indoles bearing an electron-withdrawing fluorine group (5f) or electron-donating methoxy group $(\mathbf{5} \mathbf{h})$ at their 5 -position reacted smoothly under the optimized conditions to give the desired products $8 \mathbf{i}$ and $8 \mathbf{k}$ in good yields (entries 3 and 5). However, when compound $\mathbf{5 g}$ bearing a bromine group at the 5-position of the indole was used as a substrate, a slightly lower yield (43\%) of spiroindoline $\mathbf{8 j}$ was observed. The lower yield observed in this case was attributed to side reaction(s) involving the aryl bromide moiety of the substrate, as well as the aryl bromide of the product $\mathbf{8 j}$.

We then turned our attention to the selective synthesis of the $\beta$-elimination product 9 (Table 3). It was envisaged that 9 could be efficiently produced under the same reaction conditions in the absence of an external nucleophile. This assumption was based on the results of our previous reaction, where the use of 1,2bis(diphenylphosphino)ethane (dppe) as a ligand afforded spiroindole 9a as the major product in $62 \%$ yield (Table 1 , entry 7). Contrary to our expectation, the treatment of $\mathbf{5 a}$ with $\mathrm{Pd}_{2}(\mathrm{dba})_{3} \cdot \mathrm{CHCl}_{3}(2.5 \mathrm{~mol} \%)$ and dppe $(10 \mathrm{~mol} \%)$ in the 


\section{Tetrahedron}

presence of $\mathrm{Cs}_{2} \mathrm{CO}_{3}$ (2 equiv) at $70{ }^{\circ} \mathrm{C}$ afforded the desired product 9a in only $7 \%$ yield (Table 3 , entry 1 ). Based on this disappointing result, we carefully examined the reaction parameters and screened a series of bases against the reaction (entries 2-6), including $\mathrm{Cs}_{2} \mathrm{CO}_{3}, \mathrm{Et}_{3} \mathrm{~N}$, (i-Pr) $)_{2} \mathrm{NEt}$ (DIPEA) and $\mathrm{BnNH}_{2}$ at $50-55^{\circ} \mathrm{C}$. Among them, a combination of $\mathrm{BnNH}_{2}$ and $\mathrm{Cs}_{2} \mathrm{CO}_{3}$ gave a better result (33\%, entry 6) than the reaction using $\mathrm{Cs}_{2} \mathrm{CO}_{3}$ alone (entry 1). Furthermore, the reaction temperature had a significant impact on the yield of 9a. For example, the reaction reached completion within $3 \mathrm{~h}$ at a slightly elevated temperature $\left(60{ }^{\circ} \mathrm{C}\right)$ to afford the desired product in $68 \%$ yield (Table 3, entry 7). Lowering the loading of $\mathrm{BnNH}_{2}$ (entry 8, $45 \%$ ) or increasing the loading of the catalyst (entry $9,64 \%$ ) did not improve the yield of 9a. It is noteworthy that the reaction involving the use of $\mathrm{BnNH}_{2}$ as the only base afforded only a trace amount of 9a (entry 10). Under the optimized conditions, substituted indoles $\mathbf{5 f}$ and $\mathbf{5 h}$ afforded spiroindoles $\mathbf{9 b}$ and $\mathbf{9 d}$, respectively, in moderate to good yields (entries 11 and 13). Furthermore, the brominated substrate $\mathbf{5 g}$ reacted under these conditions to $9 \mathbf{c}$, albeit in a lower yield (40\%, entry 12$)$.

Table 2. Reaction of various indoles. ${ }^{a}$
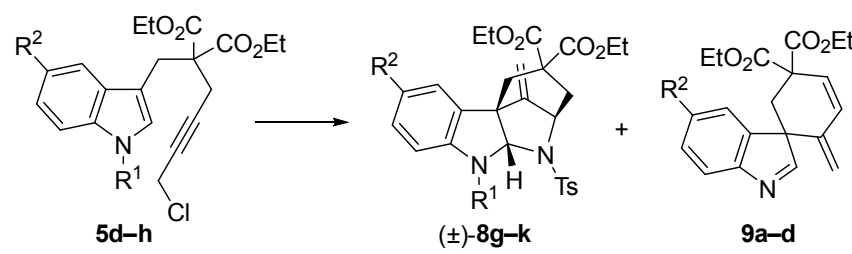

\begin{tabular}{|c|c|c|c|c|c|c|c|}
\hline \multirow{2}{*}{ entry } & \multirow{2}{*}{ subst. } & \multirow{2}{*}{$\mathrm{R}^{1}$} & \multirow{2}{*}{$\mathrm{R}^{2}$} & \multirow{2}{*}{$\begin{array}{l}\text { temp } \\
\left({ }^{\circ} \mathrm{C}\right)\end{array}$} & \multirow{2}{*}{$\begin{array}{l}\text { time } \\
\text { (h) }\end{array}$} & \multicolumn{2}{|c|}{$\%$ yield (product) ${ }^{b}$} \\
\hline & & & & & & 8 & 9 \\
\hline 1 & $5 d$ & Boc & $\mathrm{H}$ & 60 & 24 & $0 \quad(\mathbf{8 g})$ & $0 \quad(\mathbf{9 a})$ \\
\hline 2 & $5 e$ & $\mathrm{Me}$ & $\mathrm{H}$ & 60 & 24 & $\begin{array}{ll}0 & (\mathbf{8 h})\end{array}$ & $0 \quad(\mathbf{9 a})$ \\
\hline 3 & $5 f$ & $\mathrm{H}$ & $\mathrm{F}$ & $\mathrm{rt}$ & 3 & $71 \quad(\mathbf{8 i})$ & $5(9 b)$ \\
\hline 4 & $5 \mathrm{~g}$ & $\mathrm{H}$ & $\mathrm{Br}$ & 60 & 3 & $43 \quad(\mathbf{8 j})$ & $6(9 \mathrm{c})$ \\
\hline 5 & $5 \mathbf{h}$ & $\mathrm{H}$ & $\mathrm{OMe}$ & $\mathrm{rt}$ & 2.5 & $71(\mathbf{8 k})$ & $20(\mathbf{9 d})$ \\
\hline
\end{tabular}

a Reactions were carried out using propargyl chlorides $\mathbf{5 d - h}$ with $\mathrm{Pd}_{2}(\mathrm{dba})_{3} \cdot \mathrm{CHCl}_{3}(2.5 \mathrm{~mol} \%)$, dppb (10 mol \%), $\mathrm{Cs}_{2} \mathrm{CO}_{3}$ (2 equiv) and $\mathrm{TsNH}_{2}$ (1.5 equiv) in THF $(0.067 \mathrm{M}){ }^{b}$ Isolated yields.

Table 3 Synthesis of spiroindoles $\mathbf{9 a}-\mathbf{d}$.

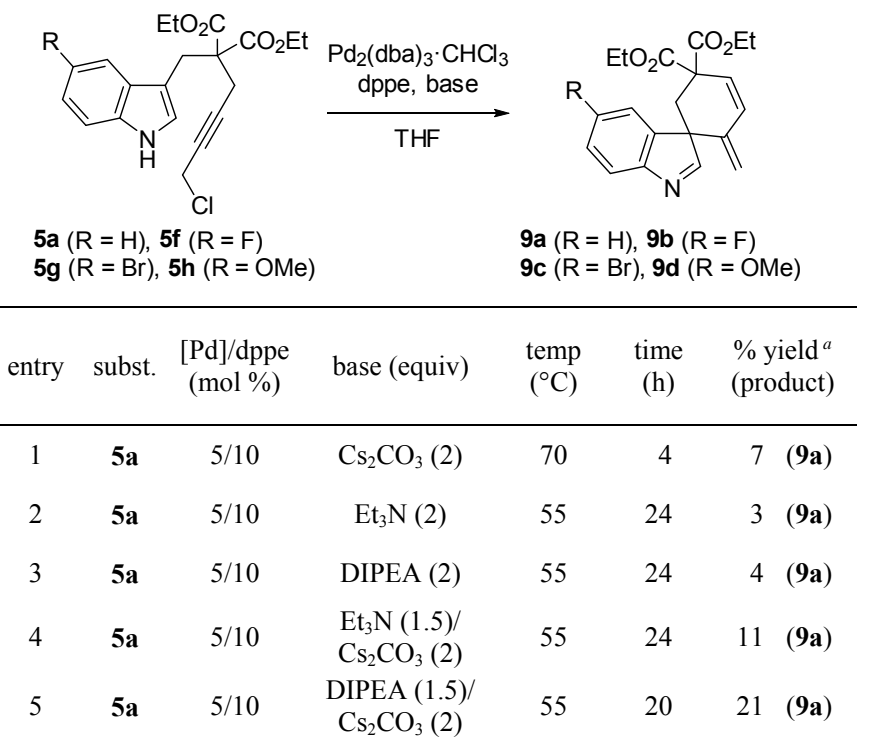

\begin{tabular}{|c|c|c|c|c|c|c|c|}
\hline 6 & $5 \mathbf{a}$ & $5 / 10$ & $\begin{array}{c}\mathrm{BnNH}_{2}(1.5) / \\
\mathrm{Cs}_{2} \mathrm{CO}_{3}(2)\end{array}$ & 55 & 24 & 33 & (9a) \\
\hline 7 & $5 \mathbf{a}$ & $5 / 10$ & $\begin{array}{c}\mathrm{BnNH}_{2}(1.5) / \\
\mathrm{Cs}_{2} \mathrm{CO}_{3}(2)\end{array}$ & 60 & 3 & 68 & (9a) \\
\hline 8 & $5 \mathbf{a}$ & $5 / 10$ & $\begin{array}{c}\mathrm{BnNH}_{2}(0.2) / \\
\mathrm{Cs}_{2} \mathrm{CO}_{3}(2)\end{array}$ & 60 & 4 & 45 & (9a) \\
\hline 9 & $5 a$ & $10 / 20$ & $\begin{array}{c}\mathrm{BnNH}_{2}(1.5) / \\
\mathrm{Cs}_{2} \mathrm{CO}_{3}(2)\end{array}$ & 60 & 3 & 64 & (9a) \\
\hline 10 & $5 a$ & $10 / 20$ & $\mathrm{BnNH}_{2}(2)$ & 60 & 24 & trace & (9a) \\
\hline 11 & $5 f$ & $5 / 10$ & $\begin{array}{c}\mathrm{BnNH}_{2}(1.5) / \\
\mathrm{Cs}_{2} \mathrm{CO}_{3}(2)\end{array}$ & 60 & 3 & 56 & (9b) \\
\hline 12 & $5 g$ & $5 / 10$ & $\begin{array}{c}\mathrm{BnNH}_{2}(1.5) / \\
\mathrm{Cs}_{2} \mathrm{CO}_{3}(2)\end{array}$ & 60 & 3 & 40 & (9c) \\
\hline 13 & $5 \mathrm{~h}$ & $5 / 10$ & $\begin{array}{c}\mathrm{BnNH}_{2}(1.5) / \\
\mathrm{Cs}_{2} \mathrm{CO}_{3}(2)\end{array}$ & 60 & 3 & 74 & (9d) \\
\hline
\end{tabular}

${ }^{a}$ Isolated yields.
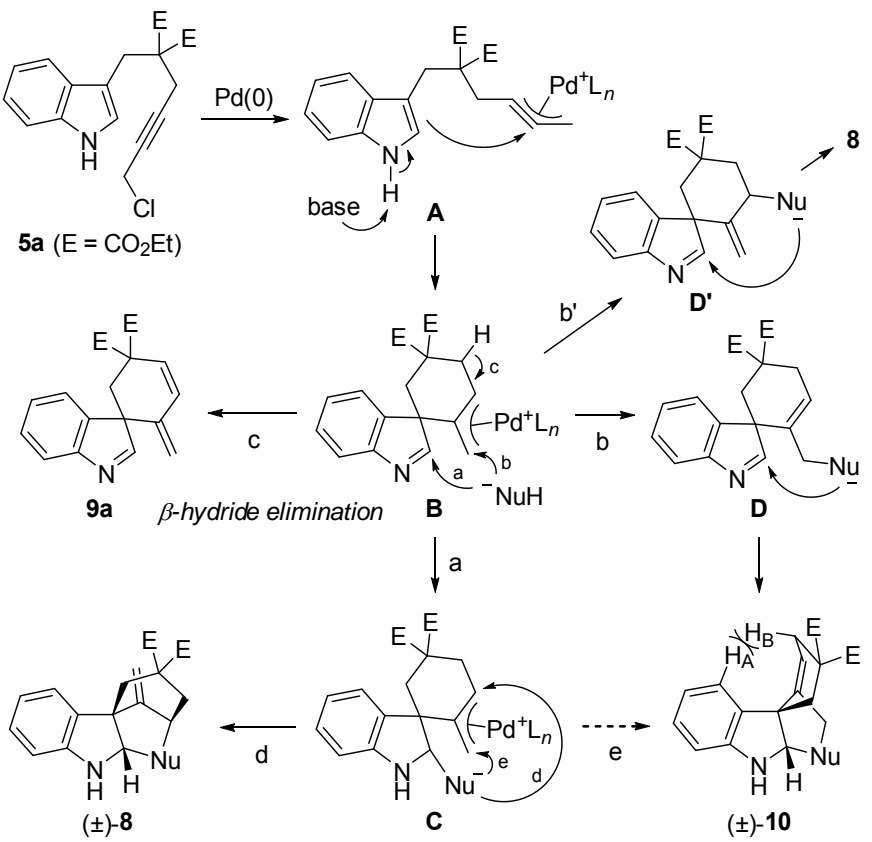

Figure 1. Proposed mechanism for palladium-catalyzed cascade cyclization.

A plausible mechanism for the cascade cyclization is shown in Figure 1. Briefly, propargyl chloride would initially react with a palladium catalyst to give the $\eta^{3}$-propargylpalladium complex A. ${ }^{18,18}$ Intramolecular nucleophilic addition of the indole to the central carbon atom of the $\eta^{3}$-propargylpalladium $\mathbf{A}$ would give $\eta^{3}$-allylpalladium complex $\mathbf{B} .{ }^{19}$ Deprotonation at the indole nitrogen would be necessary for this step, considering that the $N$ substituted substrates $\mathbf{5 d}$ and $\mathbf{5 e}$ did not react under the optimized reaction conditions (Table 2, entries 1 and 2). The tetracyclic spiroindolines $\mathbf{8}$ and $\mathbf{1 0}$ would then be formed by the intermolecular nucleophilic attack of the external nucleophile via path a and/or b. Path a represents the first intermolecular nucleophilic attack on the imine carbon, which would be followed by the allylic substitution reaction of intermediate $\mathbf{C}$. Depending on which carbons of the allylic moiety in $\mathbf{C}$ participated in the cyclization (path $\mathrm{d}$ vs. e), the regioisomeric products $\mathbf{8}$ and $\mathbf{1 0}$ would be formed. Path $\mathrm{b}$ would occur to give intermediate $\mathbf{D}$ if the intermolecular allylic substitution reaction dominated over the addition of the nucleophile to the imine, with spiroindoline 10 being formed as the major product. In this step, the occurrence of an intermolecular reaction at the more hindered carbon (path $b^{\prime}$ ) would be another possible pathway. In contrast, 
$\beta$-hydride elimination from $\mathbf{B}$ would produce diene 9a (path c). When a sulfonamide was used as the external nucleophile, tetracyclic spiroindoline $\mathbf{8}$ was obtained without producing any of the regioisomeric spiroindoline 10. This regioselectivity was most likely affected by steric hindrance during the reactions involved in path a, in that the product $\mathbf{1 0}$ as well as the transition state from $\mathbf{C}$ to $\mathbf{1 0}$ would be destabilized by unfavorable steric interactions between the indole proton at the 4-position $\left(\mathrm{H}_{\mathrm{A}}\right)$ and the flagpole hydrogen $\left(\mathrm{H}_{\mathrm{B}}\right)$ of the cyclohexene moiety. In contrast, the reaction using carbon nucleophile would favor the formation of regioisomer 10 (Scheme 4). This can be explained by considering both the sterically congested and soft characteristics of the carbon nucleophiles. Thus, the sterically hindered imine carbon (having a quaternary carbon at the neighboring position) would induce the nucleophilic attack of the soft carbon nucleophiles at the $\eta^{3}$-allylpalladium moiety of $\mathbf{B}$ to form 10 via intermediate $\mathbf{D}$ (path $\mathrm{b}){ }^{20}$

Finally, we attempted to carry out a catalytic asymmetric version of the current reaction. To the best of our knowledge, only two catalytic asymmetric reactions have been reported to date for the propargylpalladium chemistry. Rawal et al. ${ }^{14 a}$ reported an asymmetric version of the aforementioned intermolecular spirocyclization of a tryptamine-derived substrate (Scheme 2, eq 4) and obtained the spiroindole $(\mathrm{Nu}=\mathrm{NR}$ ) in $16 \%$ ee using $(R)$-BINAP. You et al. ${ }^{14 \mathrm{~b}}$ found that $(R)$-SEGPHOS showed more efficient asymmetric induction, affording the corresponding spiroindole $\left[\mathrm{Nu}=\mathrm{C}\left(\mathrm{CO}_{2} \mathrm{Et}\right)_{2}\right]$ in $52 \%$ ee. The enantio-determining step in these reactions would be the allylic substitution step, where the chiral spirocenter would be formed by the nucleophilic reaction of the indole moiety. We screened a series of chiral ligands against $\beta$-hydride elimination reaction to produce spiroindole 9a (Table 4, entries 1-8). When $(R)$ SEGPHOS and $(R)$-DM-SEGPHOS were used, these reactions produced spiroindole 9a with better enantioselectivities (51-53\% ee, entries 6 and 7), although the yields of 9a were unsatisfactory $(12-24 \%)$. We thus proceeded to examine the synthesis of tetracyclic spiroindoline 8a using $(R)$-SEGPHOS and $(R)$-DMSEGPHOS. Fortunately, the palladium-catalyzed reaction of $\mathbf{5 a}$ with $\mathrm{TsNH}_{2}$ in the presence of $\mathrm{H}_{2} \mathrm{O}$ (1 equiv) using $(R)$ SEGPHOS gave the tetracyclic spiroindoline 8a (38\% yield) and spiroindole 9a (15\% yield) with moderate enantioselectivities (65-71\% ee, entry 10). It should be noted that the addition of $\mathrm{H}_{2} \mathrm{O}$ to the reaction was necessary for a high level of reproducibility. This result therefore highlights the great potential of a propargylpalladium complex in terms of its use in catalytic asymmetric reactions.

Table 4. Optimization of the catalytic asymmetric reaction conditions. ${ }^{a, b}$

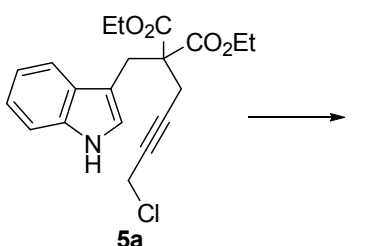

$5 a$

\begin{tabular}{cccccc}
\hline \multirow{2}{*}{ entry } & \multirow{2}{*}{ chiral ligand } & \multirow{2}{*}{$\begin{array}{c}\text { other } \\
\text { reagent }\end{array}$} & $\begin{array}{c}\text { time } \\
(\mathrm{h})\end{array}$ & \multicolumn{2}{c}{ \% yield y $^{c}(\% \text { ee })^{d}$} \\
\hline 1 & $(R)$-QUINAP & $\mathrm{BnNH}_{2}$ & 5 & - & 9a \\
\hline 2 & $(S, S)$-DIOP & $\mathrm{BnNH}_{2}$ & 3.5 & - & mixture \\
3 & $(R)$-CHIRAPHOS & $\mathrm{BnNH}_{2}$ & 7 & - & $13(13)$
\end{tabular}

\begin{tabular}{|c|c|c|c|c|c|}
\hline 4 & $(R)$-BINAP & $\mathrm{BnNH}_{2}$ & 4 & - & $22(34)$ \\
\hline 5 & (S)-SYNPHOS & $\mathrm{BnNH}_{2}$ & 6 & - & $\begin{array}{c}\text { ca. } 34 \% \\
(40)\end{array}$ \\
\hline 6 & (R)-SEGPHOS & $\mathrm{BnNH}_{2}$ & 6 & - & $12(53)$ \\
\hline 7 & $(R)$-DM-SEGPHOS & $\mathrm{BnNH}_{2}$ & 4 & - & $24(51)$ \\
\hline 8 & (R)-DIFLUORPHOS & $\mathrm{BnNH}_{2}$ & 24 & - & $5.5(34)$ \\
\hline 9 & (R)-SEGPHOS & $\mathrm{TsNH}_{2}$ & 24 & $24(56)$ & $14(73)$ \\
\hline 10 & (R)-SEGPHOS & $\begin{array}{c}\mathrm{TsNH}_{2}, \\
\mathrm{H}_{2} \mathrm{O}^{e}\end{array}$ & 14 & $38(65)$ & $15(71)$ \\
\hline 11 & (R)-DM-SEGPHOS & $\begin{array}{c}\mathrm{TsNH}_{2}, \\
\mathrm{H}_{2} \mathrm{O}^{e}\end{array}$ & 20 & $16(30)$ & $4(77)$ \\
\hline
\end{tabular}
$\mathrm{Pd}_{2}(\mathrm{dba})_{3} \cdot \mathrm{CHCl}_{3}(2.5 \mathrm{~mol} \%)$, chiral ligand $(10 \mathrm{~mol} \%), \mathrm{Cs}_{2} \mathrm{CO}_{3}(2$ equiv) and other reagent (1.5 equiv) in THF $(0.067 \mathrm{M}) .{ }^{b}$ One of the enantiomers of $8 \mathbf{a}$ is (Chiralcel IC-3) ${ }^{e}$ Reaction was carried out with addition of $\mathrm{H}_{2} \mathrm{O}$ (1 equiv).

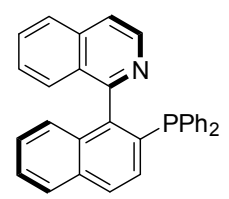

(R)-QUINAP

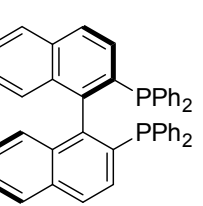

$(R)$-BINAP

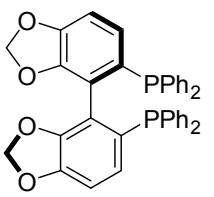

(R)-SEGPHOS

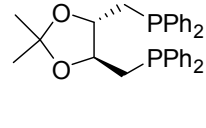

$(S, S)-D I O P$<smiles>C[C@H](P)[C@H](C)Pc1ccccc1</smiles>

\section{$(R, R)$-CHIRAPHOS}

$34 \%$

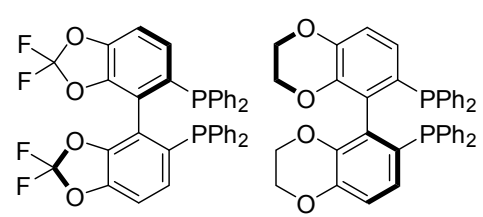

(S)-SYNPHOS

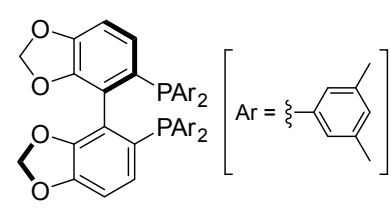

(R)-DM-SEGPHOS shown in the Scheme. ${ }^{c}$ Isolated yields. ${ }^{d}$ Determined by HPLC analysis

\section{Conclusion}

In conclusion, we have developed the palladium-catalyzed spirocyclization of propargyl chlorides using an external nucleophile for the divergent synthesis of tetracyclic spiroindolines. When this reaction was conducted in the absence of an appropriate external nucleophile, it gave the corresponding spiroindoles through $\beta$-hydride elimination. The regioselectivity of this reaction was found to be dependent on the external nucleophiles employed in the reaction. We have also investigated an asymmetric version of this reaction to produce spiroindole derivatives in $65-71 \%$ ee. This methodology would provide a novel approach to biologically active spiroindole derivatives.

\section{Experimental}

\section{General Methods.}

All reactions under argon atmosphere were performed using syringe-septum cap techniques and all glassware was dried in an oven at $80{ }^{\circ} \mathrm{C}$ for $2 \mathrm{~h}$ prior to use. For flash chromatography, silica gel (Wakosil C-200E: Wako Pure Chemical Industries, Ltd) or $\mathrm{NH}_{2}$ silica gel (Chromatorex NH-DM1020: Fuji Silysia Chemical Ltd.) was employed. Thin layer chromatography was 
performed on Merck TLC silica gel $60 \mathrm{~F}_{254}$ or Wako $\mathrm{NH}_{2}$ silica gel $60 \mathrm{~F}_{254}$ plate (layer thickness $0.25 \mathrm{~mm}$ ), which were developed using standard visualizing agents: UV fluorescence $(254 \mathrm{~nm})$ and anisaldehyde with heating. Melting points were measured by a hot stage melting point apparatus (uncorrected). ${ }^{1} \mathrm{H}$ NMR spectra were recorded using a JEOL AL-400 or JEOL ECA-500 spectrometer, and chemical shifts are reported in $\delta$ (ppm) relative to TMS as internal standard. ${ }^{13} \mathrm{C}$ NMR spectra were recorded using a JEOL AL-400 or JEOL ECA-500 spectrometer and referenced to the residual solvent signal. ${ }^{1} \mathrm{H}$ NMR spectra are tabulated as follows: chemical shift, multiplicity $(\mathrm{b}=$ broad, $\mathrm{s}=$ singlet, $\mathrm{d}=$ doublet, $\mathrm{t}=$ triplet, $\mathrm{q}=$ quartet, $\mathrm{m}=$ multiplet), number of protons, and coupling constant(s). Exact mass (HRMS) spectra were recorded on a JMS-HX/HX 110A mass spectrometer. Infrared (IR) spectra were obtained on a JASCO FT/IR-4100 FT-IR spectrometer with JASCO ATR PRO410-S

\section{General procedure for the synthesis of tetracyclic spiroindolines (8).}

To a stirred mixture of 5a (30 mg, $0.080 \mathrm{mmol})$ and $\mathrm{TsNH}_{2}(20.5$ $\mathrm{mg}, 0.12 \mathrm{mmol})$ in THF were added $\mathrm{Pd}_{2}(\mathrm{dba})_{3} \cdot \mathrm{CHCl}_{3}(2.1 \mathrm{mg}$, $3.9 \mu \mathrm{mol}, 2.5 \mathrm{~mol} \mathrm{\%})$, dppb (3.4 mg, $8.0 \mu \mathrm{mol}, 10 \mathrm{~mol} \%)$, and $\mathrm{Cs}_{2} \mathrm{CO}_{3}(52 \mathrm{mg}, 0.16 \mathrm{mmol})$ at room temperature under argon. The mixture was stirred for $3 \mathrm{~h}$ at this temperature, and $\mathrm{H}_{2} \mathrm{O}$ was added to the mixture. The whole was extracted with EtOAc. The extract was washed with $\mathrm{H}_{2} \mathrm{O}$, brine and dried over $\mathrm{MgSO}_{4}$. The filtrate was concentrated under reduced pressure to give an oily residue, which was purified by flash chromatography over $\mathrm{NH}_{2}$ silica gel with $n$-hexane-EtOAc (8:1) to give 8a (29.3 mg, $72 \%$ yield) and $9 \mathrm{a}(1.4 \mathrm{mg}, 5.2 \%$ yield $)$

\section{General procedure for the synthesis of spiroindoles (9).}

To a stirred mixture of $\mathbf{5 a}(30 \mathrm{mg}, 0.080 \mathrm{mmol})$ and $\mathrm{BnNH}_{2}(13$ $\mu \mathrm{L}, 0.12 \mathrm{mmol})$ in THF were added $\mathrm{Pd}_{2}(\mathrm{dba})_{3} \cdot \mathrm{CHCl}_{3}(2.1 \mathrm{mg}$, $3.9 \mu \mathrm{mol}, 2.5 \mathrm{~mol} \%)$, dppe (3.2 $\mathrm{mg}, 8.0 \mu \mathrm{mol}, 10 \mathrm{~mol} \%)$, and $\mathrm{Cs}_{2} \mathrm{CO}_{3}(52 \mathrm{mg}, 0.16 \mathrm{mmol})$ at $60{ }^{\circ} \mathrm{C}$ under argon. The mixture was stirred for $3 \mathrm{~h}$ at this temperature, and $\mathrm{H}_{2} \mathrm{O}$ was added to the mixture. The whole was extracted with EtOAc. The extract was washed with $\mathrm{H}_{2} \mathrm{O}$, brine and dried over $\mathrm{MgSO}_{4}$. The filtrate was concentrated under reduced pressure to give an oily residue, which was purified by flash chromatography over silica gel with $n$-hexane-EtOAc (9:1 to 8:1) to give 9a (18.5 mg, $68 \%$ yield).

\section{Asymmetric synthesis of spiroindoline (8a) and spiroindole (9a).}

To a stirred mixture of $\mathbf{5 a}(30 \mathrm{mg}, 0.080 \mathrm{mmol}), \mathrm{TsNH}_{2}(20.5 \mathrm{mg}$, $0.12 \mathrm{mmol})$ and $\mathrm{H}_{2} \mathrm{O}(1.4 \mu \mathrm{L}, 0.080)$ in THF were added $\mathrm{Pd}_{2}(\mathrm{dba})_{3} \cdot \mathrm{CHCl}_{3}(2.1 \mathrm{mg}, 3.9 \mu \mathrm{mol}, 2.5 \mathrm{~mol} \%)$, (R)-SEGPHOS (4.9 $\mathrm{mg}, 8.0 \mu \mathrm{mol}, 10 \mathrm{~mol} \%$ ), and $\mathrm{Cs}_{2} \mathrm{CO}_{3}(52 \mathrm{mg}, 0.16 \mathrm{mmol})$ at $60{ }^{\circ} \mathrm{C}$ under argon. The mixture was stirred for $14 \mathrm{~h}$ at this temperature, and $\mathrm{H}_{2} \mathrm{O}$ was added to the mixture. The whole was extracted with EtOAc. The extract was washed with $\mathrm{H}_{2} \mathrm{O}$, brine and dried over $\mathrm{MgSO}_{4}$. The filtrate was concentrated under reduced pressure to give an oily residue, which was purified by flash chromatography over $\mathrm{NH}_{2}$ silica gel with $n$-hexane-EtOAc $(10: 1$ to $8: 1)$ to give 8 a $(15.7 \mathrm{mg}, 38 \%$ yield, $65 \%$ ee [HPLC, Chiralcel-IC-3 column eluting with $65: 35 n$-hexane/i-PrOH at $0.75 \mathrm{~mL} / \mathrm{min}, t_{1}=17.98 \mathrm{~min}$ (major enantiomer), $t_{2}=26.74 \mathrm{~min}$ (minor enantiomer) $]\}$ and 9a $\{4.1 \mathrm{mg}, 15 \%$ yield and $71 \%$ ee [HPLC, Chiralcel-IC-3 column eluting with $65: 35 n$-hexane/i-
$\mathrm{PrOH}$ at $0.75 \mathrm{~mL} / \mathrm{min}, t_{1}=16.03 \mathrm{~min}$ (major enantiomer), $t_{2}=$ $39.26 \mathrm{~min}$ (minor enantiomer)]\}.

\section{Diethyl 2-[(1H-indol-3-yl)methyl]-2-(4-chlorobut-2-yn-1-} yl)malonate (5a).

Brown oil; IR (neat): $3409(\mathrm{NH}), 2242(\mathrm{C} \equiv \mathrm{C}), 1729(\mathrm{C}=\mathrm{O}) ;{ }^{1} \mathrm{H}$ NMR (500 MHz, $\left.\mathrm{CDCl}_{3}\right) \delta 1.23(\mathrm{t}, J=7.3 \mathrm{~Hz}, 6 \mathrm{H}), 2.83(\mathrm{t}, J=$ $2.2 \mathrm{~Hz}, 2 \mathrm{H}), 3.57$ (s, 2H), 4.10-4.25 (m, 6H), 7.03 (d, $J=2.4 \mathrm{~Hz}$, $1 \mathrm{H}$ ), 7.09 (ddd, $J=8.0,7.1,1.0 \mathrm{~Hz}, 1 \mathrm{H}), 7.16$ (ddd, $J=8.0,7.1$, $1.0 \mathrm{~Hz}, 1 \mathrm{H}), 7.32(\mathrm{dd}, J=8.0,1.0 \mathrm{~Hz}, 1 \mathrm{H}), 7.66(\mathrm{dd}, J=8.0,1.0$ $\mathrm{Hz}, 1 \mathrm{H}), 8.08$ (br s, $1 \mathrm{H}) ;{ }^{13} \mathrm{C}$ NMR $\left(125 \mathrm{MHz}, \mathrm{CDCl}_{3}\right) \delta 14.0$ (2C), 23.1, 27.3, 30.8, 58.2, 61.7 (2C), 78.3, 82.9, 109.6, 111.0, $118.9,119.5,122.0,123.4,128.1,135.8,170.1$ (2C). HRMS (FAB) calcd $\mathrm{C}_{20} \mathrm{H}_{21} \mathrm{ClNO}_{4}$ : $[\mathrm{M}-\mathrm{H}]^{-}, 374.1165$; found: $[\mathrm{M}-\mathrm{H}]^{-}$, 374.1168 .

Diethyl 11-methylene-1-tosyl-2,3,10,10a-tetrahydro-1H-2,5amethanoazepino[2,3-b]indole-4,4(5H)-dicarboxylate $(8 \mathrm{a})$. Colorless solid; mp 164-165 ${ }^{\circ} \mathrm{C}$; IR (neat): 3361 (NH), 1729 $(\mathrm{C}=\mathrm{O}) ;{ }^{1} \mathrm{H}$ NMR $\left(500 \mathrm{MHz}, \mathrm{CDCl}_{3}\right) \delta 1.24(\mathrm{t}, J=7.1 \mathrm{~Hz}, 3 \mathrm{H})$, $1.35(\mathrm{t}, J=7.1 \mathrm{~Hz}, 3 \mathrm{H}), 2.38(\mathrm{~s}, 3 \mathrm{H}), 2.40(\mathrm{~d}, J=13.7 \mathrm{~Hz}, 1 \mathrm{H})$, $2.48(\mathrm{~d}, J=13.7 \mathrm{~Hz}, 1 \mathrm{H}), 3.22(\mathrm{~d}, J=13.7 \mathrm{~Hz}, 2 \mathrm{H}), 4.09-4.10(\mathrm{~m}$, $1 \mathrm{H}), 4.13-4.39(\mathrm{~m}, 4 \mathrm{H}), 4.44(\mathrm{~s}, 1 \mathrm{H}), 4.66(\mathrm{~d}, J=4.1 \mathrm{~Hz}, 1 \mathrm{H})$, $4.76(\mathrm{~s}, 1 \mathrm{H}), 6.05(\mathrm{~d}, J=4.6 \mathrm{~Hz}, 1 \mathrm{H}), 6.64(\mathrm{~d}, J=7.8 \mathrm{~Hz}, 1 \mathrm{H})$, $6.82(\mathrm{dd}, J=7.8,7.8 \mathrm{~Hz}, 1 \mathrm{H}), 7.07-7.15(\mathrm{~m}, 2 \mathrm{H}), 7.25(\mathrm{~d}, J=8.2$ $\mathrm{Hz}, 2 \mathrm{H}), 7.86(\mathrm{~d}, J=8.2 \mathrm{~Hz}, 2 \mathrm{H}) ;{ }^{13} \mathrm{C} \mathrm{NMR}\left(125 \mathrm{MHz}, \mathrm{CDCl}_{3}\right) \delta$ 13.9 (2C), 21.4, 37.7, 39.9, 52.3, 57.7, 61.3, 62.1, 62.6, 84.0, $103.4,110.7,119.3,122.9,127.4$ (3C), 129.0, $129.6(2 \mathrm{C}), 137.6$, 143.2, 148.8, 151.7, 170.9, 171.3. HRMS (FAB) calcd $\mathrm{C}_{27} \mathrm{H}_{30} \mathrm{~N}_{2} \mathrm{O}_{6} \mathrm{~S}:\left[\mathrm{M}^{+}\right], 510.1825$; found: $\left[\mathrm{M}^{+}\right], 510.1832$.

\section{Diethyl 2-methylenespiro[cyclohexane-1,3'-indol]-3-ene-5,5-} dicarboxylate (9a).

Yellow oil; IR (neat): $1732(\mathrm{C}=\mathrm{O}) ;{ }^{1} \mathrm{H}$ NMR $\left(500 \mathrm{MHz}, \mathrm{CDCl}_{3}\right)$ $\delta 1.22-1.28(\mathrm{~m}, 6 \mathrm{H}), 2.37(\mathrm{~d}, J=14.3 \mathrm{~Hz}, 1 \mathrm{H}), 2.72(\mathrm{~d}, J=14.3$ $\mathrm{Hz}, 1 \mathrm{H}), 4.16-4.30$ (m, 4H), 4.56 (s, 1H), 4.87 (s, 1H), 6.18 (d, J $=10.3 \mathrm{~Hz}, 1 \mathrm{H}), 6.57(\mathrm{~d}, J=10.3 \mathrm{~Hz}, 1 \mathrm{H}), 7.27-7.35(\mathrm{~m}, 2 \mathrm{H})$, 7.37-7.43 (m, 1H), $7.66(\mathrm{~d}, J=8.0 \mathrm{~Hz}, 1 \mathrm{H}), 7.95(\mathrm{~s}, 1 \mathrm{H}) ;{ }^{13} \mathrm{C}$ NMR (125 MHz, $\left.\mathrm{CDCl}_{3}\right) \delta 13.9(2 \mathrm{C}), 35.0,55.5,60.8,62.3(2 \mathrm{C})$, $114.8,121.5,122.9,125.4,126.5,128.5,131.6,137.6,141.3$, 155.4, 169.8, 170.1, 173.9. HRMS (FAB) calcd $\mathrm{C}_{20} \mathrm{H}_{22} \mathrm{NO}_{4}$ : $[\mathrm{M}+$ $\mathrm{H}]^{+}, 340.1549$; found: $[\mathrm{M}+\mathrm{H}]^{+}, 340.1555$.

\section{2,2-Diethyl 6,6-dimethyl 3,5,6a,7-tetrahydro-1H-indeno[1,7a- b]indole-2,2,6,6-tetracarboxylate (10a).}

Yellow oil; IR (neat): $1735(\mathrm{C}=\mathrm{O}) ;{ }^{1} \mathrm{H}$ NMR $\left(500 \mathrm{MHz}, \mathrm{CDCl}_{3}\right)$ $\delta 1.13(\mathrm{t}, J=7.2 \mathrm{~Hz}, 3 \mathrm{H}), 1.23-1.28(\mathrm{~m}, 3 \mathrm{H}), 2.53(\mathrm{~d}, J=14.9 \mathrm{~Hz}$, $1 \mathrm{H}), 2.66-2.90(\mathrm{~m}, 5 \mathrm{H}), 3.68(\mathrm{~s}, 3 \mathrm{H}), 3.73(\mathrm{~s}, 3 \mathrm{H}), 4.00-4.34(\mathrm{~m}$, $5 \mathrm{H}), 4.76(\mathrm{~s}, 1 \mathrm{H}), 5.70-5.76(\mathrm{~m}, 1 \mathrm{H}), 6.53(\mathrm{~d}, J=8.0 \mathrm{~Hz}, 1 \mathrm{H})$, $6.67(\mathrm{dd}, J=8.0,8.0 \mathrm{~Hz}, 1 \mathrm{H}), 6.90(\mathrm{~d}, J=8.0 \mathrm{~Hz}, 1 \mathrm{H}), 6.99(\mathrm{dd}$, $J=8.0,8.0 \mathrm{~Hz}, 1 \mathrm{H}) ;{ }^{13} \mathrm{C}$ NMR $\left(125 \mathrm{MHz}, \mathrm{CDCl}_{3}\right) \delta 13.8,13.9$, 29.6, 29.7, 38.6, 39.9, 52.6, 52.9, 53.9, 54.7, 61.5, 65.6., 74.2, $109.4,118.0,119.4,123.6,128.2,135.0,140.9,149.6,169.3$, 170.6, 171.0, 171.8. HRMS (FAB) calcd $\mathrm{C}_{25} \mathrm{H}_{29} \mathrm{NO}_{8}:\left[\mathrm{M}^{+}\right]$, 471.1893; found: $\left[\mathrm{M}^{+}\right], 471.1901$

\section{Diethyl 6,6-diacetyl 5,6,6a,7-tetrahydro-1H-indeno[1,7a- b]indole-2,2(3H)-dicarboxylate (10b).}

Yellow oil; IR (neat): $3406(\mathrm{NH}), 1728(\mathrm{C}=\mathrm{O}) ;{ }^{1} \mathrm{H}$ NMR $(500$ $\left.\mathrm{MHz}, \mathrm{CDCl}_{3}\right) \delta 1.15(\mathrm{t}, J=7.1 \mathrm{~Hz}, 3 \mathrm{H}), 1.25(\mathrm{t}, J=7.1 \mathrm{~Hz}, 3 \mathrm{H})$, $2.01(\mathrm{~s}, 3 \mathrm{H}), 2.18(\mathrm{~s}, 3 \mathrm{H}), 2.37(\mathrm{~d}, J=14.7 \mathrm{~Hz}, 1 \mathrm{H}), 2.64-2.73(\mathrm{~m}$, $3 \mathrm{H}), 2.84-2.91(\mathrm{~m}, 2 \mathrm{H}), 4.04-4.20(\mathrm{~m}, 4 \mathrm{H}), 4.43($ br s, $1 \mathrm{H}), 4.83$ 
(s, 1H), 5.70-5.75 (m, 1H), $6.55(\mathrm{~d}, J=8.0 \mathrm{~Hz}, 1 \mathrm{H}), 6.70(\mathrm{dd}, J=$ $8.0,8.0 \mathrm{~Hz}, 1 \mathrm{H}), 6.91(\mathrm{dd}, J=8.0,1.1 \mathrm{~Hz}, 1 \mathrm{H}), 7.00$ (ddd, $J=$ 8.0, 8.0, $1.1 \mathrm{~Hz}, 1 \mathrm{H}) ;{ }^{13} \mathrm{C} \mathrm{NMR}\left(125 \mathrm{MHz}, \mathrm{CDCl}_{3}\right) \delta 13.8,13.9$, 26.3, 28.8, 29.5, 36.3, 40.4, 54.2, 55.0, 61.6 (2C), 73.3., 79.5, $110.2,117.6,119.8,123.4,128.3,136.0,141.1,149.4,170.8$, 171.7, 203.1, 204.8. HRMS (FAB) calcd $\mathrm{C}_{25} \mathrm{H}_{29} \mathrm{NO}_{6}$ : $\left[\mathrm{M}^{+}\right]$, 439.1995; found: $\left[\mathrm{M}^{+}\right], 439.2000$.

\section{Acknowledgement}

This work was supported by a Grant-in-Aid for the Encouragement of Young Scientists (A) from JSPS, Japan; Platform for Drug Design, Discovery, and Development from MEXT, Japan; research Grants from Takeda Science Foundation. A.I. and S.I. are grateful for Research Fellowships from the Japan Society for the Promotion of Science (JSPS) for Young Scientists.

\section{References and Foot notes}

$\dagger \quad$ Current address: Department of Chemistry, Faculty of Science and Technology, Keio University, 3-14-1 Hiyoshi, Kohoku-ku, Yokohama, Kanagama 223-8522, Japan

1. For reviews, see: (a) Tsuji, J ; Mandai, T. Angew. Chem., Int Ed. Engl. 1995, 34, 2589. (b) Tsuji, J. Palladium Reagents and Catalysts, New Perspectives for the 21st Century; Willey: UK, Chichester, 2004. pp 431 (c) Yoshida, M. Heterocycles 2013, 87, 1835

2. Tsuji, J.; Watanabe, H.; Minami, I.; Shimizu, I. J. Am. Chem. Soc. 1985, 107, 2196.

3. (a) Minami, I.; Yuhara, M.; Watanabe, H.; Tsuji, J. J. Organomet. Chem 1987, 334, 225. (b) Minami, I.; Yuhara, M.; Tsuji, J. Tetrahedron Lett. 1987, 28, 629.

4. Yoshida, M.; Ohno, S.; Namba, K. Angew. Chem., Int. Ed. 2013, 52, 13597.

5. (a) Duan, X.-H.; Guo, L.-N.; Bi, H.-P.; Liu, X.-Y.; Liang, Y.-M. Org. Lett. 2006, 8, 5777. (b) Guo, L.-N.; Duan, X.-H.; Bi, H.-P.; Liu, X.-Y.; Liang, Y.-M. J. Org. Chem. 2007, 72, 1538. (c) Bi, H.-P.; Guo, L.-N.; Gou, F.-R.; Duan, X.-H.; Liu, X.-Y.; Liang, Y.-M. J. Org. Chem. 2008, 73,4713

6. (a) Yoshida, M.; Nemoto, H.; Ihara, M. Tetrahedron Lett. 1999, 40 8583. (b) Yoshida, M.; Komatsuzaki, Y.; Nemoto, H.; Ihara, M. Org. Biomol. Chem. 2004, 2, 3099.

7. (a) Yoshida, M.; Ihara, M. Angew. Chem., Int. Ed. 2001, 40, 616. (b) Yoshida, M.; Fujita, M.; Ishii, T.; Ihara, M. J. Am. Chem. Soc. 2003 125, 4874. (c) Yoshida, M.; Fujita, M.; Ihara, M. Org. Lett. 2003, 5, 3325 .

8. (a) Yoshida, M.; Morishita, Y.; Fujita, M.; Ihara, M. Tetrahedron Lett 2004, 45, 1861. (b) Yoshida, M.; Morishita, Y.; Fujita, M.; Ihara, M. Tetrahedron 2005, 61, 4381.

9. (a) Ambrogio, I.; Cacchi, S.; Fabrizi, G. Org. Lett. 2006, 8, 2083. (b) Cacchi, S.; Giancarlo, F.; Eleonora, F. Synlett 2009, 1817.

10. Calliford, C. V.; Scheidt, K. A. Angew. Chem., Int. Ed. 2007, 46, 8748.

11. (a) Liu, C.-T.; Wang, Q.-W.; Wang, C.-H. J. Am. Chem. Soc. 1981, 103, 4634. (b) Verbitski, S. M.; Mayne, C. L.; Davis, R. A.; Concepcion, G P.; Ireland, C. M. J. Org. Chem. 2002, 67, 7124. (c) Numata, A.; Takahashi, C.; Ito, Y.; Takada, T.; Kawai, K.; Usami, Y.; Matsumura, E.; Imachi, M.; Ito, T.; Hasegawa, T. Tetrahedron Lett. 1993, 34, 2355. (d) Jadulco, R.; Edrada, R.; Ebel, R.; Berg, A.; Schaumann, K.; Wray, V.; Steube, K.; Proksch, P. J. Nat. Prod. 2004, 67, 78. (e) Neuss, N.; Neuss, M. N. In The Alkaloids; Brossi, A.; Suffness, M., Eds.; Academic: San Diego, 1990; Vol. 37, pp 229.

12. Nemoto, T.; Zhao, T.; Yokosaka, T.; Suzuki, Y.; Wu, R.; Hamada, Y. Angew. Chem., Int. Ed. 2013, 52, 2217.

13. A portion of this study has been reported as a preliminary communication: Iwata, A.; Inuki, S.; Oishi, S.; Fujii, N.; Ohno, N. Chem. Commun. 2014, 50, 298.

14. (a) Montgomery, T. D.; Nibbs, A. E. Zhu, Y ; Rawal, V. H. Org. Lett. 2014, 16, 3480. (b) Gao, R.-D.; Liu, C.; Dai, L-X.; Zhang, W.; You, S.L. Org. Lett. 2014, 16, 3919.

15. Jones, D. T.; Artman, G. D.; Williams, R. M. Tetrahedron Lett. 2007 48,1291
16. (a) Montury, M.; Goré, J. Synth. Commun. 1980, 10, 873. (b) Elsevier, C. J.; Meijer, J.; Tadema, G.; Stehouwer, P. M.; Bos, H. J. T.; Vermeer, P. J. Org. Chem. 1982, 47, 2194.

17. $\mathrm{Pd}_{2}(\mathrm{dba})_{3} \cdot \mathrm{CHCl}_{3}$ is one of the most efficient palladium $(0)$ sources, see: Zalesskiy, S. S.; Ananikov, V. P. Organometallics 2012, 31, 2302.

18. (a) Ohno, H.; Hamaguchi, H.; Ohata, M.; Tanaka, T. Angew. Chem., Int. Ed. 2003, 42, 1749. (b) Ohno, H.; Hamaguchi, H.; Ohata, M.; Kosaka, S.; Tanaka, T. J. Am. Chem. Soc. 2004, 126, 8744. For selected related works reported by our group, see: (c) Ohno, H.; Okano, A.; Kosaka, S.; Tsukamoto, K.; Ohata, M.; Ishihara, K.; Maeda, H.; Tanaka, T.; Fujii, N. Org. Lett. 2008, 10, 1171. (d) Inuki, S.; Yoshimitsu, Y.; Oishi, S.; Fujii, N.; Ohno, H. Org. Lett. 2009, 11, 4478. (e) Okano, A.; Oishi, S.; Tanaka, T.; Fujii, N.; Ohno, H. J. Org. Chem. 2010, 75, 3396. (f) Yoshimitsu, Y.; Inuki, S.; Oishi, S.; Fujii, N.; Ohno, H. Org. Lett. 2013, $15,3046$.

19. For a recent review on related catalytic dearomatization reactions, see: Zhuo, C.-X.; Zhang, W.; You, S.-L. Angew. Chem. Int. Ed. 2012, 51, 12662 .

20. At present, formation of $\mathbf{1 0}$ through intermediate $\mathbf{C}$ (path e) cannot be completely excluded. We performed an additional experiment with a separately prepared propargyl tosylamide $\left(S_{\times} 2\right.$ adduct from 5a) to confirm that this reaction does not proceed via the first $\mathrm{S}_{\mathrm{N}} 2$ reaction. In addition, the tetracyclic spiroindolines 8a was not obtained from the elimination product $9 \mathrm{a}$ under the reaction conditions.

\section{Supplementary Material}

Supplementary material was provided by the authors including further optimization of the reaction conditions, experimental procedures and characterization data for all new compounds. 